\title{
Survival of the Halophilic Archaeon Halovarius luteus after Desiccation, Simulated Martian UV Radiation and Vacuum in Comparison to Bacillus atrophaeus
}

Niloofar Feshangsaz, et al. [full author details at the end of the article]

Received: 7 February 2020 / Accepted: 20 May 2020 /Published online: 2 July 2020

(C) The Author(s) 2020

\begin{abstract}
Extraterrestrial environments influence the biochemistry of organisms through a variety of factors, including high levels of radiation and vacuum, temperature extremes and a lack of water and nutrients. A wide variety of terrestrial microorganisms, including those counted amongst the most ancient inhabitants of Earth, can cope with high levels of salinity, extreme temperatures, desiccation and high levels of radiation. Key among these are the haloarchaea, considered particularly relevant for astrobiological studies due to their ability to thrive in hypersaline environments. In this study, a novel haloarchaea isolated from Urmia Salt Lake, Iran, Halovarius luteus strain DA50T, was exposed to varying levels of simulated extraterrestrial conditions and compared to that of the bacteria Bacillus atrophaeus. Bacillus atrophaeus was selected for comparison due to its welldescribed resistance to extreme conditions and its ability to produce strong spore structures. Thin films were produced to investigate viability without the protective influence of cell multi-layers. Late exponential phase cultures of Hvr. luteus and B. atrophaeus were placed in brine and phosphate buffered saline media, respectively. The solutions were allowed to evaporate and cells were encapsulated and exposed to radiation, desiccation and vacuum conditions, and their post-exposure viability was studied by the Most Probable Number method. The protein profile using High Performance Liquid Chromatography and Matrix Assisted Laser Desorption/Ionization bench top reflector time-offlight are explored after vacuum and UV-radiation exposure. Results showed that the change in viability of the spore-forming bacteria $B$. atrophaeus was only minor whereas $H v r$. luteus demonstrated a range of viability under different conditions. At the peak radiation flux of $10^{5} \mathrm{~J} / \mathrm{m}^{2}$ under nitrogen flow and after two weeks of desiccation, Hvr. luteus demonstrated the greatest decrease in viability. This study further expands our understanding of the boundary conditions of astrobiologically relevant organisms in the harsh space environment.
\end{abstract}

Keywords Halovarius luteus · Bacillus atrophaeus · Desiccation · Mars simulation chamber . Simulated Martian UV radiation · Vacuum 


\section{Introduction}

Various missions with an astrobiology component have been sent to Mars, and two upcoming flagship missions, ExoMars (Vago et al. 2017) and Mars2020 (Mustard et al. 2013), will search for indicators of life, past or present, with a greater capacity than ever before.

There are many signatures of life, from biomolecules to viable microbes, and it is important to understand the ability of these biosignatures to survive and persist, as the most stable signatures may still be preserved and have the potential to be detected during future missions.

There are numerous methods to study the survival of microorganisms in simulated extraterrestrial environments, both in Earth orbit (Cottin et al. 2017) and in simulated conditions on Earth (Martins et al. 2017).

Ultraviolet (UV) radiation is ubiquitous in the Solar System and it is understood that UV radiation causes damage to cells and increases the rate of DNA mutation and eventually leads to death (Horneck 1999). UV radiation is grouped into three bands: UVA (315-400 nm), UVB (280-315 nm), and UVC (200-280 nm). Although UVB and UVC make up only $2 \%$ of the entire solar spectrum, these wavelengths are the ones primarily responsible for cell damage due to the high absorption of this wavelength range by DNA (Henning et al. 1995; Mancinelli 2015).

The stress factor of solar UV radiation was also very important during the Archean era as the Earth lacked an ozone layer and thus the surface was exposed to the complete spectrum of solar radiation (Monk et al. 1994). As a result, it is hypothesized that microorganisms which evolved on the Archean surface under these conditions may retain cellular mechanisms which developed to cope with elevated levels of full-spectrum UV radiation (Wynn-Williams et al. 2001).

In addition to whole microorganisms and spores, isolated biomolecules such as DNA, amino acids and liposomes have also been studied (De La Torre et al. 2010; Nicholson et al. 2000; Stan-Lotter and Fendrihan 2015).

Vacuum conditions and desiccation are two other key detrimental factors which affect microbial survival in the space environment. If there are no internal or external matrices protecting the cells, vacuum and desiccation can cause severe lesions (Dose and Gill 1995). Structural variations lead to functional alterations, such as changes in membrane permeability, inhibited or altered enzyme activity and variations of genetic information that can give rise to cell death or mutagenesis (Mancinelli 2015). Humidity reduction by desiccation can likewise impose ultimately lethal effects on microorganisms, especially in the case of non-spore forming strains. A degree of desiccation tolerance is present in a variety of organisms, including bacteria, archaea, yeast, lichens, fungus, plants, insects and crustaceans (Crowe et al. 1992; Csonka and Hanson 1991; Tepfer et al. 2012).

Halophilic archaea are some of the most primitive inhabitants of hypersaline environments in Earth's history (Oren and Mana 2002). Geological structures from the Permian and Triassic (290-206 Ma ago) have been found to contain viable archaea and bacteria, demonstrating their tolerance of desiccation (Fendrihan et al. 2009; Huu et al. 1999; McGenity et al. 2000; Norton and Grant 1988; Vreeland et al. 2000). Stromatolites 3.5 billion years in age may have been one of the first microenvironments to shelter life (Awramik 2006). Ancient halite has been demonstrated to preserve living microorganisms for more than $400 \mathrm{Ma}$; both stromatolites and halite are habitats for the archaeal family Halobacteriaceae (Leuko et al. 2010) which may have high degree of longevity (Grant et al. 1998; Landis 2001). It has also been shown that halophiles can endure the extreme conditions of desiccation, starvation and radiation exposure 
for millions of years inside stromatolites and ancient halite (Leuko et al. 2010; Stan-Lotter and Fendrihan 2015; Vreeland et al. 2007).

It is likely that many of the coping strategies of these cells relate to the Precambrian era when the UV-shielding ozone layer was not yet formed (Baqué et al. 2013). Particularly relevant studies of halophilic archaea have been performed which include Halobacterium salinarium NRC-1 under UV radiation, vacuum and desiccation (Fendrihan et al. 2009; Kottemann et al. 2005; Leuko et al. 2015), Haloccoccus morrhuae, Halococcus hamelinensis, Natronorubrum sp. strain HG-1, Hcc. Dombrowskii under UV radiation (Leuko et al. 2015; Peeters et al. 2010; Vreeland et al. 2000), Natrialba magadii, Haloferax volcanii under vacuum (Abrevaya et al. 2011), and Halorubrum chaoviator under UV radiation and vacuum (Mancinelli 2015).

Developing a mechanism for repairing DNA lesions is essential for life in hypersaline environments (Kottemann et al. 2005). Microorganisms that live in salt depositevaporated crusts demonstrate high resistance against desiccation, vacuum conditions and UV radiation (Rothschild and Lister 2003). Survival mechanisms for prokaryotic microorganisms under desiccating conditions include spore-formation (Nicholson et al. 2000) and the production of extracellular polysaccharide (Hill et al. 1997). However, these two mechanisms are not present in most halophilic archaea. Genetic analysis of Halobacterium sp. indicates that its genes are active in all DNA damage repair pathways that can be found either in eukaryotes or bacteria, pathways such as photo-reactivation, base excision repair, nucleotide excision repair, mismatch repair homologous recombination and translation synthesis (Crowley et al. 2006; Kottemann et al. 2005). While most microorganisms use organic compounds to protect against extreme osmotic pressure, halophilic archaea use $\mathrm{K}^{+}$to fulfil the same function for salt-in mechanism and $\mathrm{Na}^{+} / \mathrm{H}^{+}$for salt-out mechanism (Mancinelli 2015; Singh et al. 2013). They also use $\mathrm{Na}^{+} / \mathrm{H}^{+}$antiporter proteins related to $\mathrm{Na}$ efflux to extrude $\mathrm{Na}$ out of the cell in exchange for $\mathrm{H}^{+}$in order to keep cytoplasm isosmotic with the environment and thus elude intoxication of living cells (Han et al. 2019; Roberts 2005; Yang et al. 2006). For radiation protection, and associated damage due to hydroxyl radical production, halophilic archaea utilize protective mechanisms such as polyploidy, membrane pigments such as C50, bacterioruberin and intracellular KCl (Shahmohammadi et al. 1998; Siefermann-Harms 1987).

Varying amounts of salt have been found in each of the Shergotty, Nakhla, and Chassigny (SNC) Mars meteorites (Gooding 1992), and indeed the Nakhla meteorite may have been in contact with sea water/brine on Mars (Sawyer et al. 2000), while the Mars Exploration Rovers (MER) and the Mars Express orbiter have detected salt and evaporated mineral surfaces on present-day Mars (Bibring et al. 2005). Even if the temperature of early Mars was below $273 \mathrm{~K}$ (Gaidos and Marion 2003), the probability of liquid water is high based on the presence of dissolved minerals in the system (Fairén et al. 2009). The capability of haloarchaea to survive in low water-activity conditions, such as evaporating environments, and their requirement for a high salt concentrations, make them suitable models to study life on Mars (Dassarma et al. 2019; Litchfield 1998).

In the present work, we investigated the survival of two different microorganisms in simulated space and Mars-surface conditions: the halophilic archaeon Hvr. luteus strain $\mathrm{DA} 50^{\mathrm{T}}$ and the spore-forming bacteria $B$. atrophaeus. Samples were desiccated in petri dishes. They were exposed to simulated Mars-relevant levels of UV-radiation, vacuum and desiccation conditions and their survivability was studied by the semi-quantitative Most Probable 
Number (MPN) method (Sutton 2010) and shift in protein profiles of the halophiles was analyzed by HPLC and MALDI-TOF. The result of this research illustrates the survival capacity of halophilic archaeon under simulated space and Mars conditions. It is well known that haloarchaea are excellent candidates for astrobiological studies, not only for their ability to survive salinity near saturation like on Mars (Mancinelli et al. 2004) or Jupiter's moon Europa (Marion et al. 2003), but also because of their ability to cope with a variety of extreme conditions such as desiccation, radiation, extreme $\mathrm{pH}$ and temperature (Abrevaya et al. 2011).

\section{Materials and Methods}

\section{Microorganisms and Culture Media}

An extremely halophilic archaeon Halovarius luteus genus novel, species novel strain DA50 ${ }^{\mathrm{T}}$, belonging to Halobacteriaceae family, was isolated from a brine sample collected in 2011 from Urmia Salt Lake ( $37^{\circ} 32^{\prime} \mathrm{N}, 45^{\circ} 43^{\prime} \mathrm{E}$ ) located in north west Iran. This lake was one of the largest supersaturated hypersaline lakes in the world (Alipour 2006; Alipour and Mosavi Onlaghi 2018). Geological formations surrounding the Urmia Salt Lake consist of Jurassic limestone and Eocene volcanic rocks (Alipour 2006) and this hypersaline environment provides a habitat for a plethora of life-forms including various species of bacteria, archaea, algae, micro fungi and plants (Asem et al. 2014). Over the last four decades, Urmia Salt Lake has dramatically reduced in extent due to overexploitation of water for agricultural purposes, reduction in precipitation, increased evaporation, and the construction of dams to supply potable water to urban districts (Amiri et al. 2016). The lake salinity has increased from $166 \mathrm{~g} / \mathrm{l}$ in 1995 to over $412 \mathrm{~g} / \mathrm{l}$ in 2015, and its resident halophilic microorganisms, more of which are identified every year, are plentiful (Amiri et al. 2016; Mehrshad et al. 2015). It was therefore decided that, instead of using a model haloarchaeon, a novel strain which evolved in an increasingly saturated brine should be used to study biological response under simulated extraterrestrial conditions.

To compare the survival of this halophile strain under extreme conditions a bacterium Bacillus atrophaeus (formerly Bacillus subtilis var. niger) was used (Sella et al. 2015). The bacterium was selected since it is a well-established control organism for comparisons in extreme environments for its high resistance to extreme conditions and the capability to produce strong spore structures consisting of coat, cortex, outer membrane, germ cell wall, inner membrane and core (Carrera et al. 2007; Halfmann et al. 2007; Irie et al. 2014; Sella et al. 2015). The strain was obtained from Spordex Biological Indicator Strips (Bacillus atrophaeus nrrl\#4418, Steris, USA) and spores were aseptically transferred to modified soy bean casein digest broth. B. atrophaeus is a facultative anaerobic, gram-positive and rod that makes endospores (Sella et al. 2009). After activation in liquid culture medium, the strain was cultivated in Trypticase Soy Broth. The late log phase samples were used for analysis. B. atrophaeus was grown at $35{ }^{\circ} \mathrm{C}$ in a shaking incubator (Stuart-Orbit incubator S150) at $150 \mathrm{rpm}$. For $H v r$. luteus optimum growth was maintained in $4 \mathrm{M} \mathrm{NaCl}$ and $0.3 \mathrm{M} \mathrm{MgCl}_{2}$. The optimum temperature and $\mathrm{pH}$ for growth was $45^{\circ} \mathrm{C}$ and 7.0, respectively (Mehrshad et al. 2015). This strain was obtained from Iranian Biological Research Center (IBRC) as an active culture. The culture medium, modified growth medium (MGM) 23\% (w/v) (Dyall-Smith 2008), contains a $23 \%$ salt mixture which consists of [g l ${ }^{-1}$ ]: $184 \mathrm{NaCl}, 26.83 \mathrm{MgSO}_{4} \cdot 7 \mathrm{H}_{2} \mathrm{O}$, $23 \mathrm{MgCl}_{2} \cdot 6 \mathrm{H}_{2} \mathrm{O}, 7.76 \mathrm{KCl}, 1 \mathrm{CaCl}_{2} \cdot 2 \mathrm{H}_{2} \mathrm{O}, 0.61 \mathrm{NaBr}, 0.15 \mathrm{NaHCO}_{3}$. The culture medium 
was supplemented with $3 \mathrm{~g}$ peptone casein, $1 \mathrm{~g}$ peptone proteose, $1 \mathrm{~g}$ nutrient broth, $2 \mathrm{~g}$ yeast extract, and $18 \mathrm{~g}$ agar for solid medium. To increase the growth rate, $0.5 \mathrm{~mL}$ vitamin $\mathrm{B} 12$, $1 \mathrm{~mL}$ B-complex and $400 \mu \mathrm{L}$ of trace element SL-10 solution $(10 \mathrm{mg} / \mathrm{L} \mathrm{HCl}(25 \% ; 7.7 \mathrm{M})$,

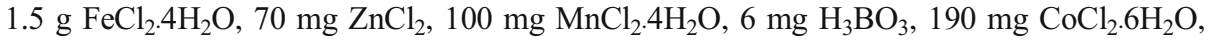
$2 \mathrm{mg} \mathrm{CuCl} 2 \cdot 2 \mathrm{H}_{2} \mathrm{O}, 24 \mathrm{mg} \mathrm{NiCl} 2 \cdot 6 \mathrm{H}_{2} \mathrm{O}, 36 \mathrm{mg} \mathrm{Na} 2 \mathrm{MoO}_{4} \cdot 2 \mathrm{H}_{2} \mathrm{O}, 990 \mathrm{~mL}$ distilled water) was added to the medium. The medium was sterilized by autoclaving at $121{ }^{\circ} \mathrm{C}$. The liquid cultures were prepared at $38{ }^{\circ} \mathrm{C}$ (due to the water temperature at the time of sampling) in a shaking incubator (Stuart-Orbit incubator S150) at $200 \mathrm{rpm}$. Growth rate was monitored turbidometrically for more than $300 \mathrm{~h}$ with a spectrophotometer (Hach Langer Dr. 5000, USA) at $\mathrm{OD}_{600}$.

\section{Preparing and Growth of Microorganisms}

Microbial films were produced at three different thicknesses (A, B and C) from cultures in the late log phase (see Fig. 1A, B, C). $\mathrm{OD}_{600}$ of 0.8-1.0 for Hvr. luteus strain DA50 ${ }^{\mathrm{T}}$ and 1.0-1.2 for $B$. atrophaeus, which corresponded to cell densities of $3 \times 10^{8}$ and $2.5 \times 10^{7}$ per $\mathrm{mL}$, respectively. The approximate cell number in each thickness are $\mathrm{A}=1.5 \times 10^{9} / 5 \mathrm{~mL}, \mathrm{~B}=3 \times$ $10^{9} / 10 \mathrm{~mL}, \mathrm{C}=6 \times 10^{9} / 20 \mathrm{~mL}$ for halophiles. With a petri dish surface area of $24.6 \mathrm{~cm}^{2}$ and Hvr. luteus cell size of $\sim 1 \mu \mathrm{m}$ (Mehrshad et al. 2015), the average cell coverage for thickness A, B and C was approximately $0.6,1.2$ and 2.4 cells $/ \mu \mathrm{m}^{2}$, respectively. Cells were harvested by centrifugation at $4000 \mathrm{~g}$ for $10 \mathrm{~min}$ at room temperature (RT). The pellets of Hvr. luteus strain $\mathrm{DA} 50^{\mathrm{T}}$ and $B$. atrophaeus were resuspended three times in the buffers $(3 \mathrm{M} \mathrm{NaCl}$, $100 \mathrm{mM}$ Tris, $\mathrm{pH}=7.5$ and phosphate buffered saline (PBS) $1 \mathrm{X}, \mathrm{pH}=7.4$, for halophile and bacillus respectively) to remove the nutrients around the cells. Hvr. luteus strain DA50 ${ }^{\mathrm{T}}$ cells are obligate halophiles, requiring a minimum of $2 \mathrm{M} \mathrm{NaCl}$. After the final wash, the pellets were suspended in the given solutions and poured into $5.6 \mathrm{~cm}$ diameter petri dishes. The samples were shaken inside a laminar flow bench for at least $5 \mathrm{~h}$ at RT and $20 \mathrm{rpm}$ and allowed to dry completely.

\section{Simulated Space Conditions}

\section{UV-Radiation}

Desiccated samples (thicknesses A, B and C) were exposed to UV radiation under both ambient and $\mathrm{N}_{2}$ atmosphere (a cylinder between UV source and sample was continuously vented by $\mathrm{N}_{2}$ ), using a broadband, high pressure xenon short arc polychromic lamp without reflector (wavelength of 200-400 nm, ScienceTech, model 100150XUV, XBO $150 \mathrm{~W} / 4$,
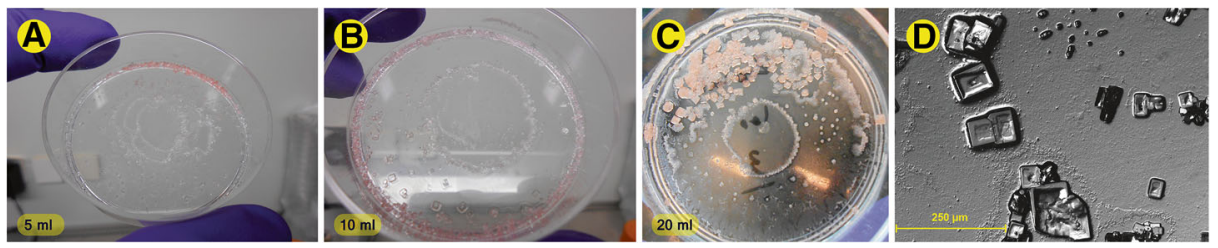

Fig. 1 Hvr. luteus strain DA50 $0^{\mathrm{T}}$ encased in salt crystals during preparation for further experiments. Desiccated plates, diameter $5.6 \mathrm{~cm}$ with preliminary volume of (A) $5 \mathrm{~mL},(\mathbf{B}) 10 \mathrm{~mL}$ and (C) $20 \mathrm{~mL}$. (D) Light microscope image of a plate of $H v r$. luteus strain DA $50^{\mathrm{T}}(40 \mathrm{X})$ showing details of the mineral formed after desiccation 
XBO, Japan) for various time periods $(0, \sim 1.8,18,182$ and $1825 \mathrm{~s})$. The irradiance of the broadband lamp was calculated to be $54.78 \mathrm{~W} / \mathrm{m}^{2}$ (lamp power $150 \mathrm{~W}$; distance between UV source and sample at $47 \mathrm{~cm}$ ) whereas the lamp intensity was measured at the monochromatic wavelength of $254 \mathrm{~nm}$ (VLX-3 W, UVC $254 \mathrm{~nm}$, Vilber, Germany) was $2.90 \mathrm{~W} / \mathrm{m}^{2}$ under ambient and $3.15 \mathrm{~W} / \mathrm{m}^{2}$ under $\mathrm{N}_{2}$ atmosphere, an increase of about $8 \%$. In comparison, Mars receives an estimated $34 \mathrm{~W} / \mathrm{m}^{2}$ (Peeters et al. 2010). The UV-air and UV- $\mathrm{N}_{2}$ control samples were kept in a laminar flow bench and an $\mathrm{N}_{2}$ chamber, respectively.

\section{Vacuum Tests}

To investigate the impact of vacuum conditions, cells at thickness B (see Section 2.2) were installed in a vacuum chamber which was evacuated by a scroll pump in combination with a turbomolecular pump. Low-vacuum tests were conducted at $1.7 \times 10^{-1} \mathrm{mbar}$ (only scroll pump operating) for $1 \mathrm{~h}$ and 7 days. High-vacuum tests were conducted at $1.6 \times 10^{-5}$ mbar for $1 \mathrm{~h}$, and $7.6 \times 10^{-8}$ mbar for 7 days. Control samples were kept under ambient pressure and temperature in dark conditions.

\section{Desiccation}

Cultures of both strains at thickness C (see Section 2.2) were desiccated using two different methods inside petri dishes. In the first method, the samples were placed in a desiccator along with a $230 \mathrm{~g}$ blue silica gel cartridge (Bel-art SP Scienceware Desiccant, USA). In the second method, the dishes were placed in the laminar flow bench with closed lids and exposed to ambient atmosphere. For both methods the materials were desiccated for 2 weeks. During the tests, salt crystals were formed (see Fig. 1D). Control samples were processed in the same way, but were not placed inside a laminar flow bench nor a desiccator.

\section{Determination of Survivability}

The concentration of living cells after the sample treatment was determined using the MPN method (Blodgett 2006; Sutton 2010). For growth and reproductive viability, nine test tubes consisting of $9 \mathrm{~mL}$ of the relevant liquid culture medium (either MGM 23\% or Tryptic Soy Broth) were prepared for each sample. For recovery of the cells, $3 \mathrm{~mL}$ of the given buffer (Tris$\mathrm{NaCl}$ and PBS for halophile and bacillus, respectively) were added to each dry sample and stirred for homogenization. After dissolution of the samples at RT, $1 \mathrm{~mL}$ of the solution (buffer mixed with recovered cells) was transferred to each prepared test tube (final total volume of $10 \mathrm{~mL}$ ). From these solutions (a 1:10 dilution from the original $1 \mathrm{~mL}$ sample), a dilution series of three tubes were made: $1: 10,1: 100$, and 1:1000. These dilution series were incubated at $38^{\circ} \mathrm{C}$ for 3 weeks for $H v r$. luteus strain DA50 , and $35^{\circ} \mathrm{C}$ for 2 days for B. atrophaeus to reach late log phase.

\section{Protein Profile}

A simple and fast method was developed for the extraction of proteins from haloarchaea strain Hvr. luteus DA50T (Dyall-Smith 2008; Holland et al. 1999; Wall et al. 1999). In brief, the whole protein from a cell lysate supernatant was extracted after lysis with B-PER Reagent extracts proteins (B-PER® Bacterial Protein Extraction Reagent, Thermo Scientific, USA), 
$2 \mathrm{~mL}$ Tris- $\mathrm{NaCl}$ buffer was added to the plates and were shaken for $30 \mathrm{~min}$ inside a laminar flow cabinet to avoid sample contamination. Subsequently, cell pellets were collected by centrifugation at $4000 \mathrm{~g}$ for $10 \mathrm{~min}$. Pellets were transferred to a $2 \mathrm{~mL}$ micro centrifuge tube and centrifuged for a second time at 11,000 g for $10 \mathrm{~min}$, both at RT. At this point, $1 \mathrm{~mL}$ of BPER Reagent extract proteins was added to each sample and vortexed. Cell pellets were sonicated three times for $30 \mathrm{~s}$ and cooled on ice between each sonication (Branson Sonifier 250). Samples were then shaken for $30 \mathrm{~min}$ and centrifuged at $10,000 \mathrm{~g}$ for $20 \mathrm{~min}$ at $4{ }^{\circ} \mathrm{C}$ to pellet cell membranes and unbroken cells. The supernatant was transferred to a fresh tube and stored at $-20{ }^{\circ} \mathrm{C}$ for later analysis.

For protein profiling, $700 \mu \mathrm{L}$ of supernatant was fractionated using Reversed-Phase High Performance Liquid Chromatography (RP-HPLC) (Jasco, Japan) using a C18 column as a qualitative method. Elution was performed with a linear gradient, from 5 to $65 \%$ acetonitrile containing $0.1 \%$ trifluoroacetic acid (TFA) for $30 \mathrm{~min}$ at flow rate of $4 \mathrm{~mL} / \mathrm{min}$. The absorbance of the column effluent was monitored at $214 \mathrm{~nm}$ (Thermo Finnigan detector, San Jose, CA). The mass identification of the proteins or peptides in each fraction was obtained by Matrix Assisted Laser Desorption/Ionization bench top reflector time-of-flight (MALDI-TOF) mass spectrometer (Micro Flex MALDI-TOF of Bruker Daltonics, Germany). The concentrated fractions were processed with MALDI-TOF. $50 \mu \mathrm{L}$ of TFA (containing trifluoroacetic acid $0.1 \%$, acetonitrile $30 \%$, and milli-Q water) solution was added to each fraction and the mixture was well vortexed. Next, $4 \mu \mathrm{L}$ of concentrated protein mixed with TFA was combined with $\alpha$-Cyano-4-hydroxy-cinnamic acid ( $\alpha$-HCCA) matrix solution (MALDI-MS) in 1:1 ratio and $2 \mu \mathrm{L}$ of this was spotted on a stainless steel MALDI target and dried at ambient air. After crystallization of the samples, the determination of the protein fragments was obtained in the reflector mode to compare results from different culture conditions.

\section{Results}

\section{Determination of Survival after UV Irradiation}

Whereas no loss of viability of $B$. atrophaeus occurred following a UV irradiation exposure of up to $10^{5} \mathrm{~J} / \mathrm{m}^{2}$, the viability of haloarchaea was clearly reduced (Fig. 2). At the lowest dose $\left(10^{2} \mathrm{~J} / \mathrm{m}^{2}\right)$ the results of MPN tests demonstrated that the thinnest film (A, $\left.5 \mathrm{~mL}\right)$, which there is no overlap among cells, of haloarchaeon showed less growth even in the control samples in comparison with other groups (B: 10 and C: $20 \mathrm{~mL}$ ). Conversely, samples B and C showed no loss of viability in air, with the samples B decreasing in viability $23 \%$ under UV exposure with $\mathrm{N}_{2}$ (Fig. 2). It is worth mentioning that, cells in thickness $\mathrm{B}$ has a little bit overlaps $\sim 1.2$ cell/ $1 \mu \mathrm{m}^{2}$; however, thickness $\mathrm{C}$ showed an obvious overlap among the cells $\sim 2.4$ cell $/ 1 \mu \mathrm{m}^{2}$.

By increasing the dose of UV radiation, the samples with least thickness showed the largest decrease in viability, especially in combination with $\mathrm{N}_{2}$. Samples at $10^{3} \mathrm{~J} / \mathrm{m}^{2}$ and $10^{4} \mathrm{~J} / \mathrm{m}^{2}$ with thickness A showed 59\% and 32\% viability in combination with air, and $39 \%$ and $30 \%$ in combination with $\mathrm{N}_{2}$ (Fig. 2). For thicknesses $\mathrm{B}$ and $\mathrm{C}$, a slight decline continued following exposure of $10^{3}$ and $10^{4} \mathrm{~J} / \mathrm{m}^{2}$ so that thickness $\mathrm{B}$ showed $76 \%$ and $52 \%$ viability in combination with air and $61 \%$ and $40 \%$ viability under $\mathrm{N}_{2}$. Thickness $\mathrm{C}$ demonstrated $82 \%$ viability for both doses in air and $65 \%$ and $52 \%$ with $\mathrm{N}_{2}$. At $10^{5} \mathrm{~J} / \mathrm{m}^{2}$ irradiation with thickness A there is a $12 \%$ viability while thickness B displayed a $16 \%$ to $15 \%$ viability and thickness $\mathrm{C}$ 


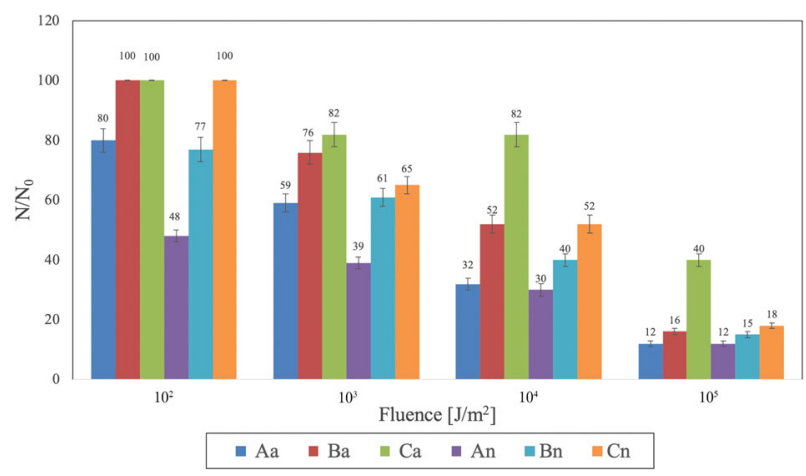

Fig. $2 H v r$. luteus strain DA50 ${ }^{\mathrm{T}}$ survival after exposure for $10^{2}-10^{5} \mathrm{~J} / \mathrm{m}^{2}$ of UV-radiation under a air and under $\mathrm{N}_{2}$. Aa, Ba and $\mathrm{Ca}$ are UV-air exposed samples and $\mathrm{An}, \mathrm{Bn}$ and $\mathrm{Cn}$ are $\mathrm{UV}-\mathrm{N}_{2}$ exposed samples (where A, B and $\mathrm{C}$ refer to the sample thickness). The error bars are the $95 \%$ confidence intervals for three independent experiments $(n=3)$. The survival percentages $\mathrm{N} / \mathrm{N}_{0}$ are given above each bars, where $\mathrm{N}$ is the number of

demonstrated the highest viability: $40 \%$ and $18 \%$ in air and $\mathrm{N}_{2}$ at $10^{5} \mathrm{~J} / \mathrm{m}^{2}$. Note that no reduction of viability was detected for $B$. atrophaeus under either atmospheric test.

\section{Effect of Vacuum Exposure}

The survival of Hvr. luteus strain DA50 $0^{\mathrm{T}}$ and B. atrophaeus to low- and high-vacuum conditions was evaluated (Fig. 3). Under these conditions, the MGM 23\% medium formed large halite crystals in which the cells were trapped. Cultures of strain DA50 ${ }^{\mathrm{T}}$ and B. atrophaeus at thickness B were prepared for these exposure experiments. For both strains there was no significant difference in survival after $1 \mathrm{~h}$ in low and high vacuum condition exposures, and for $B$. atrophaeus no reduction of viability was detected even after 7 days exposure. The reduction of survival of Hvr. luteus to $61 \%$ after 7 days is statistically lower than the control samples in the 7 days groups.

\section{Survival after Desiccation}

As seen in Fig. 4, both cell strains did not show a viability change after 1 week of desiccation in the laminar flow bench. Further, B. atrophaeus did not show a decreased viability when placed in desiccator for 1 week, while Hvr. luteus demonstrated a decrease to $79.6 \%$ viability. Both organisms showed decreased in viability when exposed to 2 weeks desiccation in a laminar flow bench and a desiccator. For B. atrophaeus the viability was $55 \%$ in the desiccator and $85 \%$ in the laminar flow bench after two weeks. For Hvr. luteus the final viabilities were $15.1 \%$ and $59.2 \%$, respectively.

\section{HPLC and MALDI-TOF Protein Profiles}

The chromatograms of UV-radiation and vacuum-exposed samples are presented in Fig. 5A, B. HPLC was used to separate the mixtures of proteins and peptides based on their affinity to immobilized stationary phase. While the retention time for most peaks are either compatible with the control samples or have only minor shifts, there are some exceptions: peaks at minute 3 in UV-air which show a dramatically high mAU, while at minutes 17 to 19 , 


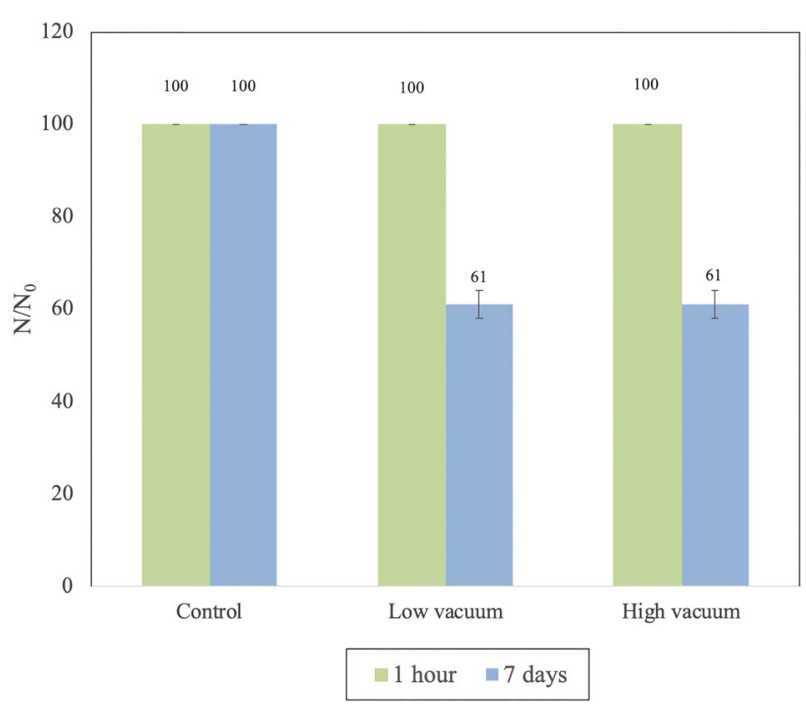

Fig. 3 The percentage of survival of $H v r$. luteus strain DA50 $0^{\mathrm{T}}$ exposed low $\left(1.7 \times 10^{-1} \mathrm{mbar}\right)$ and high vacuum $1 \mathrm{~h}$ at $1.6 \times 10^{-5} \mathrm{mbar}$ and 7 days at $7.6 \times 10^{-8} \mathrm{mbar}$ in compare with control samples. The standard error bar of $95 \%$ confidence intervals for three independent experiments $(n=3)$ is indicated. The survival percentages $N / N_{0}$ are given above each bar, where $\mathrm{N}$ is the number of survivors specified by the MPN technique and $\mathrm{N}_{0}$ is the number of surviving cells in control samples

all UV exposed samples show higher peaks than control samples. At minute 25, all exposed samples show weaker peaks than control samples (Fig. 5A).

In the vacuum measurements shown in Fig. 5B, a reverse peak can be observed at 3 min for high vacuum conditions, while for both high and low vacuum conditions an intense signal can be observed in minute 18 .

Fractions were separated in minutes and subsequently analyzed by MALDI-TOF. The MALDI-TOF protein spectra of one of the clearer qualities of vacuum exposed samples, minute 13, are shown in Fig. 6. The minute 13 fraction was chosen since this provided clear

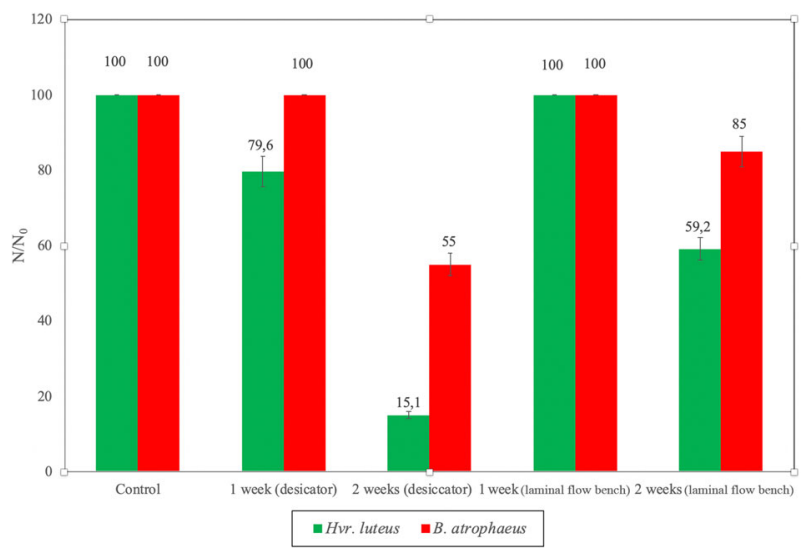

Fig. $4 H v r$. luteus strain DA50 ${ }^{\mathrm{T}}$ (green) and B. atrophaeus (red) exposed to desiccation for 1 and 2 weeks. The standard error bar of $95 \%$ confidence intervals for three independent experiments $(n=3)$ is indicated. The survival percentages $\mathrm{N} / \mathrm{N}_{0}$ of both strains are given on top of the bar charts where $\mathrm{N}$ is the number of survivors specified by the MPN technique and $\mathrm{N}_{0}$ is the number of surviving cells in control samples 

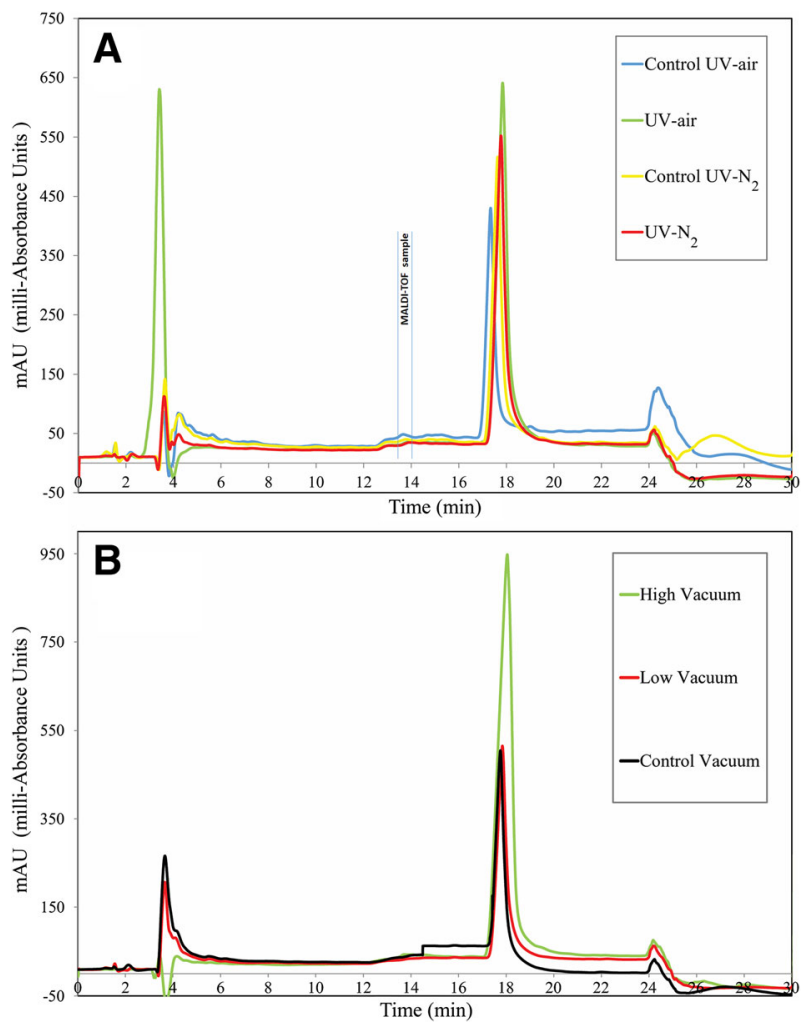

Fig. 5 RP-HPLC chromatograms (milli-Absorbance Units/Time) of proteome profiles of Hvr. luteus strain DA50 ${ }^{\mathrm{T}}$ after exposure to UV radiation either with air or with $\mathrm{N}_{2}$ (A) and to low and high vacuum conditions (B). The slice at $13 \mathrm{~min}$ is used for additional MALDI-TOF analysis (See Fig. 6)

spectra compared to other time fractions. Several changes in protein profiles between the control sample and vacuum exposed samples in the 13-min fractions can be observed. For instance, in the proteins below $3 \mathrm{kDa}$ in the control sample (Fig. 6 blue line), some proteins appeared at masses 2267, 2629, $2854 \mathrm{Da}$. In sample exposed to low vacuum condition (Fig. 6 yellow line), the weights are 2288, 2690 and $2854 \mathrm{Da}$ are quite similar to the control sample, while in the high vacuum condition exposed sample (Fig. 6 red line) the protein at weight $2959 \mathrm{Da}$, as well as some others, are deviating compared to the control sample. In the proteins above $3 \mathrm{kDa}$, the control sample shows several peaks which are absent in both vacuum samples, with the exception of the peak with the masses of 3531 and $4102 \mathrm{Da}$ in the low vacuum samples. In the high vacuum exposed sample, peaks at 3360, 3723 and 4100 Da can be observed.

\section{Discussion}

In this study, we explored the resistance of halite-embedded cells of Hvr. luteus strain DA50 ${ }^{\mathrm{T}}$ and PBS-embedded cells of resistant bacteria B. atrophaeus to UV radiation (200-400 nm), low and high vacuum conditions, and desiccation. Hvr. luteus strain DA50 ${ }^{\mathrm{T}}$ was exposed to various UV fluxes under both air and $\mathrm{N}_{2}$ atmosphere, and it remained viable even after more 


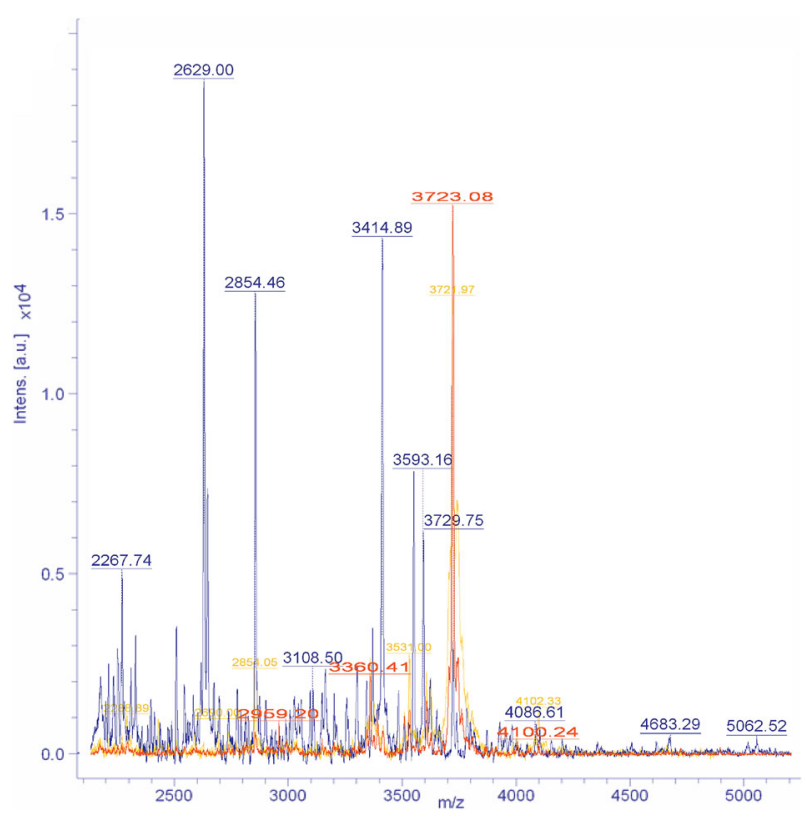

Fig. 6 MALDI-TOF spectrum obtained from vacuum control (blue), low vacuum (yellow) and high vacuum (red) samples in minute 13 after purification and fraction by RP-HPLC (See Fig. 5)

than half an hour exposure to simulated Mars UV radiation. In experiments involving UV transmission through air, while the presence of oxygen has an attenuating effect on the effective radiation level, the oxygen may in turn be the source of oxygen radicals, which can directly damage the cells. If the latter effect is indeed present and dominant, such an effect was not observed in our results. Taken into account that $\mathrm{NaCl}$ crystals are translucent to wavelengths $\geq 200 \mathrm{~nm}$ (Li 1976), damage to Hvr. luteus from UV radiation could be due to the formation of ${ }^{\circ} \mathrm{OH}$ radicals produced by UV radiation from residual water molecules inside the halite crystals and/or intercellular fluid. These data suggest that a lower initial cell thickness (A) may have contributed to the lower survival rate of the Hvr. luteus for UV radiation. Cell multi-layers aiding survivability is well characterized (Mancinelli 2015). However, the maximum lethal effect occurred when the single-layer samples exposed to UV fluxes in combination with $\mathrm{N}_{2}$. The novel haloarchaeon, Hvr. luteus represented more viability when the single-layer arrangement was changed to a multi-layer: 2.4 cells $/ 1 \mu \mathrm{m}^{2}$ and more growth under air and nitrogen (Fig. 2). In all other combinations of culture thickness and radiation it is clear that radiation transmitted through a $\mathrm{N}_{2}$ atmosphere has a higher lethal impact compared to oxygen containing atmosphere.

Fendrihan and colleagues exposed halite-entrapped Halococcus dombrowskii to simulated Mars UV radiation and the archaeon survived at doses even up to $10^{7} \mathrm{~J} / \mathrm{m}^{2}$. This survival rate was two times more than in liquid medium with the same dose (Fendrihan et al. 2009). In regard to UV-radiation, MacCready and colleagues (McCready et al. 2005) tested the resistance of Halobacterium NRC-1 and D. radiodurans against UVC doses up to $200 \mathrm{~J} / \mathrm{m}^{2}$. It appeared that both microorganisms are highly resistant. Peeters and colleagues (Peeters et al. 2010) exposed Natronorubrum strain HG-1 under desiccation and UV-radiation (200-400 nm, $28 \mathrm{~W} / \mathrm{m}^{2}$ ) to represent a Mars-like surface. Results showed that the strain was able to withstand 
the UV radiation exposure only for a couple of hours. It could not withstand the combination of radiation with desiccation and low temperatures. A related species, H. chaoviator, has demonstrated tolerance to UV radiation doses of up to $10^{7} \mathrm{~J} / \mathrm{m}^{2}$, showing that survival capabilities are not necessarily shared between phylogenetically related species (Mancinelli et al. 1998). Zhou and colleagues (Zhou et al. 2007) showed that Halobacterium sp. NRC-1, Haloarcula marismortui and Haloquadratum walsbyi have optimized their proteomic and genomic structures to decrease damage induced by UV irradiation which often exists at high levels in habitats where these organisms thrive. The data from our study demonstrate that B. atrophaeus is more UV-radiation, vacuum and desiccation resistant than Hvr. luteus strain $\mathrm{DA}^{\mathrm{T}}{ }^{\mathrm{T}}$ (Figs. 3 and 4). Although, for survival under desiccation, adaptations of many prokaryotes include sporulation (Nicholson et al. 2000) or production of extracellular polysaccharides (Potts 1994), neither of them are utilized by the well-studied halophile, Halobacterium sp. (Kottemann et al. 2005). While the positive effect of multi-layering and halite-embedded cells seem irrefutable, it appears that multiple protective mechanisms are influencing haloarchaea survivability.

Another factor that may contribute to the resistance of halophilic archaea to high levels of UV radiation, alongside with the presence of multiple genome copies, is the high concentration of intracellular halide ions including chloride and possibly bromide that play the role of chemical chaperones (Abrevaya et al. 2011; Kish et al. 2009). It has been demonstrated that H. salinarum NRC-1 benefits from bromide ions that accumulate with chloride ions in its natural brines (Kish et al. 2009; Sonnenfeld and Perthuisot 1984). It has been proved that the levels of bromide and chloride ions have increased in Urmia Salt-Lake from1994 to2009: 2.5 and 6.3 times for chloride and bromide, respectively (Rezvantalab and Amrollahi 2011). With the declining water level in Urmia Salt-Lake continuing for over four decades, the chemical dynamic of the lake could compel some new survival mechanisms to its inhabitants.

The survival of Hvr. luteus strain DA50 ${ }^{\mathrm{T}}$ at thickness B to low- and high-vacuum and at thickness $\mathrm{C}$ to desiccation was evaluated. Under these conditions, the medium formed large salt crystals in which the cells were embedded (Fig. 1). Under vacuum while B. atrophaeus showed no loss of viability a moderate decrease in the survival of Hvr. luteus was observed (Fig. 3). In a comparable experimental setup, the endurance and stability of the vegetative Halobacterium sp. falls short compared to Bacillus subtilis while exposed to vacuum $\left(10^{-8}\right.$ mbar $)$ and low temperatures $\left(-196{ }^{\circ} \mathrm{C}\right)$ for $24 \mathrm{~h}$. While the latter remained viable at $75 \%$, all $\mathrm{H}$. halobium cells were overserved to be dead (Koike et al. 1992; Kottemann et al. 2005). In a 10-day experiment with the cells embedded in a Mars soil analogue under low pressure D. radiodurans showed $30 \%$ viability, while E. coli did not survive (Diaz and Schulze-Makuch 2006). Kottemann et al. (2005) demonstrated that Halobacterium sp. strain $\mathrm{NRC}-1$ is highly resistant to desiccation and high vacuum $\left(10^{-8} \mathrm{mbar}\right)$. The viability dropped only gradually, so that after 20 days the viability reduced to only $25 \%$ and there was no significant difference between viable cells either in vacuum or in desiccation measurements. These results suggest that halite crystals that formed during the experiment offered a level of cellular protection. Abrevaya and colleagues (Abrevaya et al. 2011), compared two haloarchaea Natrialba magadii and Haloferax volcanii with D. radiodurans under high vacuum conditions $\left(10^{-7} \mathrm{mbar}\right)$. The results demonstrated that $N$. magadii was more resistant than $D$. radiodurans to such low pressures. High resistance in $N$. magadii may have been due to the more effective mechanisms of halophiles against desiccation. Hvr. luteus strain DA50 ${ }^{\mathrm{T}}$ indicated a dramatic decline (a decrease of $84.9 \%$ ) in viability at desiccation experiment since the humidity was highly reduced due to two weeks of desiccation inside desiccator. 
Nevertheless, in all desiccation methods $B$. atrophaeus showed a higher viability percentage, $H v r$. luteus strain $\mathrm{DA} 50^{\mathrm{T}}$ has shown a good degree of resistance, too. The ability to cope with low active water for halophiles is most likely related to their salt tolerance. The Halobacteriaceae family responds to increases in osmolarity by means of $\mathrm{K}^{+}$as their osmoticum (Kushner 1968; Mancinelli 2015). Osmotic pressure increases during dehydration is similar to a cell in a hypersaline environment (Mancinelli 2015).

In regard to protein profiles, the HPLC chromatograms for the UV-exposed samples showed some overlap between groups except for the higher peak at $3 \mathrm{~min}$ for UV-air and a slightly higher peak at $25 \mathrm{~min}$ for UV-air control sample. There seems to be even more overlap between groups in the vacuum experiment except for the high peak for the samples exposed to high vacuum at $18 \mathrm{~min}$. Initial MALDI-TOF analysis demonstrated different mass spectra in low molecular weight regions after exposing cells to vacuum conditions. This indicates that under such conditions cells are able to change their metabolism, via novel metabolic pathways, or protein expressions to survive the harsh environmental conditions. This demonstrates the need for future studies using a more analytical proteomic approach using, for example, trypsin digestion for high mass molecular proteins to produce small fragments or peptides for MS-MS analysis, comparing these with the library of known MALDI-TOF spectral fingerprints and masses predicted from haloarchaea proteomic databases such as the HAMAP database (Lima et al. 2009). One could also apply Isotope-Coded Protein Labeling (ICPL) for comparing different extreme environments (Tebbe et al. 2009).

The current MALDI-TOF profiles suggest changes of the cell lysate fractions by the amino acid degradation or modification induced during the exposure to the simulated space environment. Changes might have affected single peptides or the polypeptides profile in the cells involved in stress responses during such extreme conditions in order to adapt their physiology and cellular structures. Many archaeal cell envelopes are composed of an atypical cellular membrane constituted by isoprenyl ether glycerol phospholipids surrounded by surface S-layer proteins as the component of the cell wall (Albers and Meyer 2011). This lipid stability of the archaea membrane is able to serve as a shell against harsh conditions and could be investigated in more detail in future work.

\section{Conclusion}

This study is the first work reporting the survival of a novel extremely halophilic archaeon compared to a resistant spore-forming bacterium under simulated space conditions. Hvr. luteus strain DA50 $0^{\mathrm{T}}$ and B. atrophaeus were exposed to different regimes of simulated solar radiation (200-400 $\left.\mathrm{nm}, 54.78 \mathrm{~W} / \mathrm{m}^{2}\right)$, low $\left(\sim 10^{-1} \mathrm{mbar}\right)$ and high $\left(\sim 10^{-5}-10^{-8} \mathrm{mbar}\right)$ vacuum conditions, and desiccation. Hvr. luteus strain $\mathrm{DA} 50^{\mathrm{T}}$ showed a good resistance, withstanding 30 min of Mars simulated UV radiation under air or $\mathrm{N}_{2}$ atmosphere, high vacuum conditions, and up to two weeks desiccation. Survival within brine inclusions may be another method by which Hvr. luteus strain $\mathrm{DA} 50^{\mathrm{T}}$ cells can tolerate radiation, high vacuum conditions, and desiccation. General protein profiles show a clear difference between the various extreme conditions used. The present study suggests that this extremely halophilic archaeon may be a suitable candidate for ongoing astrobiological research.

Acknowledgements The authors would like to acknowledge the ESA-ESTEC, TEC-MMG Life, Physical Sciences and Life Support Laboratory in Noordwijk (NL) and especially Mr. A. Dowson and Mr. R. Lindner 
for hosting and supporting this study. A. Riedo acknowledges the support from the European Union's Horizon 2020 research and innovation program under the Marie Skłodowska-Curie grant agreement No. 750353. Acknowledge support for J. van Loon via ESA contract 4000107455/12/NL/PA. We would like to acknowledge Prof. T. Forouzanfar from Amsterdam UMC location VUmc for his support during the realization of this study. We thank Prof. Pascale Ehrenfreund for her hospitality making use of the vacuum and UV set-up in her lab. Finally, we like to thank ACTA faculty for their hospitality in welcoming N. Feshangsaz for this study.

\section{Compliance with Ethical Standards}

Author Disclosure Statement No competing financial interests exist.

Open Access This article is licensed under a Creative Commons Attribution 4.0 International License, which permits use, sharing, adaptation, distribution and reproduction in any medium or format, as long as you give appropriate credit to the original author(s) and the source, provide a link to the Creative Commons licence, and indicate if changes were made. The images or other third party material in this article are included in the article's Creative Commons licence, unless indicated otherwise in a credit line to the material. If material is not included in the article's Creative Commons licence and your intended use is not permitted by statutory regulation or exceeds the permitted use, you will need to obtain permission directly from the copyright holder. To view a copy of this licence, visit http://creativecommons.org/licenses/by/4.0/.

\section{References}

Abrevaya XC, Paulino-Lima IG, Galante D, Rodrigues F, Mauas PJ, Cortón E, Lage CDAS (2011) Comparative survival analysis of Deinococcus radiodurans and the Haloarchaea Natrialba magadii and Haloferax volcanii exposed to vacuum ultraviolet irradiation. Astrobiology 11:1034-1040

Albers S-V, Meyer BH (2011) The archaeal cell envelope. Nat Rev Microbiol 9:414-426

Alipour S (2006) Hydrogeochemistry of seasonal variation of Urmia salt lake, Iran. Saline Systems 2:9

Alipour S, Mosavi Onlaghi K (2018) Mineralogy and geochemistry of major, trace and rare earth elements in sediments of the Hypersaline Urmia Salt Lake, Iran. Acta Geol Sin-Eng1 92:1384-1395

Amiri V, Nakhaei M, Lak R, Kholghi M (2016) Geophysical, isotopic, and hydrogeochemical tools to identify potential impacts on coastal groundwater resources from Urmia hypersaline Lake, NW Iran. Environ Sci Pollut Res 23:16738-16760

Asem A, Eimanifar A, Djamali M, De Los Rios P, Wink M (2014) Biodiversity of the hypersaline Urmia Lake national park (NW Iran). Diversity 6:102-132

Awramik SM (2006) Respect for stromatolites. Nature 441:700-701

Baqué M, Viaggiu E, Scalzi G, Billi D (2013) Endurance of the endolithic desert cyanobacterium Chroococcidiopsis under UVC radiation. Extremophiles 17:161-169

Bibring J-P, Langevin Y, Gendrin A, Gondet B, Poulet F, Berthé M, Soufflot A, Arvidson R, Mangold N, Mustard J (2005) Mars surface diversity as revealed by the OMEGA/Mars express observations. Science 307:1576-1581

Blodgett, R. 2006. Appendix 2: most probable number from serial dilutions. Food And Drug Administration-Fda. Bacteriological Analytical Manual on line. Disponivelxem

Carrera M, Zandomeni R, Fitzgibbon J, Sagripanti JL (2007) Difference between the spore sizes of Bacillus anthracis and other Bacillus species. J Appl Microbiol 102:303-312

Cottin H, Kotler JM, Billi D, Cockell C, Demets R, Ehrenfreund P, Elsaesser A, D'hendecourt L, van Loon JJ, Martins Z (2017) Space as a tool for astrobiology: review and recommendations for experimentations in earth orbit and beyond. Space Sci Rev 209:83-181

Crowe JH, Hoekstra FA, Crowe LM (1992) Anhydrobiosis. Annu Rev Physiol 54:579-599

Crowley DJ, Boubriak I, Berquist BR, Clark M, Richard E, Sullivan L, Dassarma S, McCready S (2006) The uvrA, uvrB and uvrC genes are required for repair of ultraviolet light induced DNA photoproducts in Halobacterium sp. NRC-1. Saline Systems 2:11

Csonka LN, Hanson AD (1991) Prokaryotic osmoregulation: genetics and physiology. Annu Rev Microbiol 45: 569-606

Dassarma P, Capes MD, Dassarma S (2019) Comparative genomics of halobacterium strains from diverse locations. Microbial Diversity in the Genomic Era. Elsevier 
De La Torre R, Sancho LG, Horneck G, De Los Ríos A, Wierzchos J, Olsson-Francis K, Cockell CS, Rettberg P, Berger T, De Vera J-PP (2010) Survival of lichens and bacteria exposed to outer space conditions-results of the Lithopanspermia experiments. Icarus 208:735-748

Diaz B, Schulze-Makuch D (2006) Microbial survival rates of Escherichia coli and Deinococcus radiodurans under low temperature, low pressure, and UV-irradiation conditions, and their relevance to possible martian life. Astrobiology 6:332-347

Dose K, Gill M (1995) DNA stability and survival of Bacillus subtilis spores in extreme dryness. Orig Life Evol Biosph 25:277-293

Dyall-Smith M (2008) The Halohandbook: protocols for haloarchaeal genetics. Haloarchaeal Genetics Laboratory, Melbourne, p 14

Fairén AG, Davila AF, Gago-Duport L, Amils R, McKay CP (2009) Stability against freezing of aqueous solutions on early Mars. Nature 459:401-404

Fendrihan S, Bérces A, Lammer H, Musso M, Rontó G, Polacsek TK, Holzinger A, Kolb C, Stan-Lotter H (2009) Investigating the effects of simulated Martian ultraviolet radiation on Halococcus dombrowskii and other extremely halophilic archaebacteria. Astrobiology 9:104-112

Gaidos, E. \& Marion, G. 2003. Geological and geochemical legacy of a cold early Mars. J Geophys Res Planets: 108

Gooding JL (1992) Soil mineralogy and chemistry on Mars: possible clues from salts and clays in SNC meteorites. Icarus 99:28-41

Grant WD, Gemmell RT, McGenity TJ (1998) Halobacteria: the evidence for longevity. Extremophiles 2:279-287

Halfmann H, Denis B, Bibinov N, Wunderlich J, Awakowicz P (2007) Identification of the most efficient VUV/ UV radiation for plasma based inactivation of Bacillus atrophaeus spores. J Phys D Appl Phys 40:59075911

Han S-B, Hou X-J, Wu C, Zhao Z, Ju Z, Zhang R, Cui H-L, Keen LJ, Xu L, Wu M (2019) Complete genome sequence of Salinigranum rubrum GX10T, an extremely halophilic archaeon isolated from a marine solar saltern. Mar Genomics 44:57-60

Henning KA, Li L, Iyer N, McDaniel LD, Reagan MS, Legerski R, Schultz RA, Stefanini M, Lehmann AR, Mayne LV (1995) The Cockayne syndrome group A gene encodes a WD repeat protein that interacts with CSB protein and a subunit of RNA polymerase II TFIIH. Cell 82:555-564

Hill DR, Keenan TW, Helm RF, Potts M, Crowe LM, Crowe JH (1997) Extracellular polysaccharide of Nostoc commune (cyanobacteria) inhibits fusion of membrane vesicles during desiccation. J Appl Phycol 9:237-248

Holland RD, Duffy CR, Rafii F, Sutherland JB, Heinze TM, Holder CL, Voorhees KJ, Lay JO Jr (1999) Identification of bacterial proteins observed in MALDI TOF mass spectra from whole cells. Anal Chem 71: 3226-3230

Horneck G (1999) European activities in exobiology in earth orbit: results and perspectives. Adv Space Res 23:381-386

Huu NB, Denner EB, Ha DT, Wanner G, Stan-Lotter H (1999) Marinobacter aquaeolei sp. nov., a halophilic bacterium isolated from a Vietnamese oil-producing well. Int J Syst Evol Microbiol 49:367-375

Irie K, Scott A, Hasegawa N (2014) Investigation of the detection ability of an intrinsic fluorescence-based bioaerosol detection system for heat-stressed Bacteria. PDA J Pharm Sci Technol 68:478-493

Kish A, Kirkali G, Robinson C, Rosenblatt R, Jaruga P, Dizdaroglu M, Diruggiero J (2009) Salt shield: intracellular salts provide cellular protection against ionizing radiation in the halophilic archaeon, Halobacterium salinarum NRC-1. Environ Microbiol 11:1066-1078

Koike J, Oshima T, Koike K, Taguchi H, Tanaka R, Nishimura K, Miyaji M (1992) Survival rates of some terrestrial microorganisms under simulated space conditions. Adv Space Res 12:271-274

Kottemann M, Kish A, Iloanusi C, Bjork S, Diruggiero J (2005) Physiological responses of the halophilic archaeon Halobacterium sp. strain NRC1 to desiccation and gamma irradiation. Extremophiles 9:219-227

Kushner D (1968) Halophilic bacteria. Advances in applied microbiology, 10, 73-99

Landis GA (2001) Martian water: are there extant halobacteria on Mars? Astrobiology 1:161-164

Leuko S, Rothschild L, Burns B (2010) Halophilic archaea and the search for extinct and extant life on Mars. J Cosmol 5:940-950

Leuko S, Domingos C, Parpart A, Reitz G, Rettberg P (2015) The survival and resistance of Halobacterium salinarum NRC-1, Halococcus hamelinensis, and Halococcus morrhuae to simulated outer space solar radiation. Astrobiology 15:987-997

Li H (1976) Refractive index of alkali halides and its wavelength and temperature derivatives. J Phys Chem Ref Data 5:329-528

Lima T, Auchincloss AH, Coudert E, Keller G, Michoud K, Rivoire C, Bulliard V, De Castro E, Lachaize C, Baratin D (2009) HAMAP: a database of completely sequenced microbial proteome sets and manually curated microbial protein families in UniProtKB/Swiss-Prot. Nucleic Acids Res 37:D471-D478

Litchfield CD (1998) Survival strategies for microorganisms in hypersaline environments and their relevance to life on early Mars. Meteorit Planet Sci 33:813-819 
Mancinelli R (2015) The affect of the space environment on the survival of Halorubrum chaoviator and Synechococcus (Nägeli): data from the space experiment OSMO on EXPOSE-R. Int J Astrobiol 14:123-128

Mancinelli R, White M, Rothschild L (1998) Biopan-survival I: exposure of the osmophiles Synechococcus sp.(Nageli) and Haloarcula sp. to the space environment. Adv Space Res 22:327-334

Mancinelli R, Fahlen T, Landheim R, Klovstad M (2004) Brines and evaporites: analogs for Martian life. Adv Space Res 33:1244-1246

Marion GM, Fritsen CH, Eicken H, Payne MC (2003) The search for life on Europa: limiting environmental factors, potential habitats, and Earth analogues. Astrobiology 3:785-811

Martins Z, Cottin H, Kotler JM, Carrasco N, Cockell CS, De La Torre Noetzel R, Demets R, De Vera J-P, D'hendecourt L, Ehrenfreund P (2017) Earth as a tool for astrobiology —a European perspective. Space Sci Rev 209:43-81

McCready S, Müller JA, Boubriak I, Berquist BR, Ng WL, Dassarma S (2005) UV irradiation induces homologous recombination genes in the model archaeon, Halobacterium sp. NRC-1. Saline Systems 1:3

McGenity TJ, Gemmell RT, Grant WD, Stan-Lotter H (2000) Origins of halophilic microorganisms in ancient salt deposits: Minireview. Environ Microbiol 2:243-250

Mehrshad M, Amoozegar MA, Makhdoumi A, Rasooli M, Asadi B, SCHUMANN P, Ventosa A (2015) Halovarius luteus gen. nov., sp. nov., an extremely halophilic archaeon from a salt lake. Int J Syst Evol Microbiol 65:2420-2425

Monk JD, Clavero MRS, Beuchat LR, Doyle MP, Brackett RE (1994) Irradiation inactivation of Listeria monocytogenes and Staphylococcus aureus in low-and high-fat, frozen and refrigerated ground beef. J Food Prot 57:969-974

Mustard J, Adler M, Allwood A, Bass D, Beaty D, Bell J, Brinckerhoff W, Carr M, Des Marais D, Brake B (2013) Report of the Mars 2020 science definition team. Mars Explor Progr Anal Gr:155-205

Nicholson WL, Munakata N, Horneck G, Melosh HJ, Setlow P (2000) Resistance of Bacillus endospores to extreme terrestrial and extraterrestrial environments. Microbiol Mol Biol Rev 64:548-572

Norton CF, Grant WD (1988) Survival of halobacteria within fluid inclusions in salt crystals. Microbiology 134: 1365-1373

Oren A, Mana L (2002) Amino acid composition of bulk protein and salt relationships of selected enzymes of Salinibacter ruber, an extremely halophilic bacterium. Extremophiles 6:217-223

Peeters Z, Vos D, Ten Kate I, Selch F, van Sluis C, Sorokin DY, Muijzer G, Stan-Lotter H, van Loosdrecht M, Ehrenfreund P (2010) Survival and death of the haloarchaeon Natronorubrum strain HG-1 in a simulated martian environment. Adv Space Res 46:1149-1155

Potts M (1994) Desiccation tolerance of prokaryotes. Microbiol Mol Biol Rev 58:755-805

Rezvantalab, S. \& Amrollahi, M. H. 2011. Investigation of recent changes in Urmia salt lake. International Journal of Chemical and Environmental Engineering, 2

Roberts MF (2005) Organic compatible solutes of halotolerant and halophilic microorganisms. Saline systems 1:5

Rothschild L, Lister A (2003) Evolution on planet earth: impact of the physical environment, Elsevier

Sawyer DJ, McGehee MD, Canepa J, Moore CB (2000) Water soluble ions in the Nakhla martian meteorite. Meteorit Planet Sci 35:743-747

Sella SRBR, Guizelini BP, Vandenberghe LPDS, Medeiros ABP, Soccol CR (2009) Lab-scale production of Bacillus atrophaeus' spores by solid state fermentation in fifferent types of bioreactors. Braz Arch Biol Technol 52:159-170

Sella SR, Vandenberghe LP, Soccol CR (2015) Bacillus atrophaeus: main characteristics and biotechnological applications-a review. Crit Rev Biotechnol 35:533-545

Shahmohammadi HR, Asgarani E, Terato H, Saito T, Ohyama Y, Gekko K, Yamamoto O, Ide H (1998) Protective roles of bacterioruberin and intracellular $\mathrm{KCl}$ in the resistance of Halobacterium salinarium against DNA-damaging agents. J Radiat Res 39:251-262

Siefermann-Harms D (1987) The light-harvesting and protective functions of carotenoids in photosynthetic membranes. Physiol Plant 69:561-568

Singh SP, Raval V, Purohit MK (2013) Strategies for the salt tolerance in Bacteria and Archeae and its implications in developing crops for adverse conditions. Plant Acclimation to Environmental Stress. Springer

Sonnenfeld, P. \& Perthuisot, J.-P. 1984. Brines and evaporites, Wiley Online Library

Stan-Lotter H, Fendrihan S (2015) Halophilic archaea: life with desiccation, radiation and oligotrophy over geological times. Life 5:1487-1496

Sutton S (2010) The most probable number method and its uses in enumeration, qualification, and validation. J Valid Technol 16:35-38

Tebbe A, Schmidt A, Konstantinidis K, Falb M, Bisle B, Klein C, Aivaliotis M, Kellermann J, Siedler F, Pfeiffer F (2009) Life-style changes of a halophilic archaeon analyzed by quantitative proteomics. Proteomics 9: 3843-3855 
Tepfer D, Zalar A, Leach S (2012) Survival of plant seeds, their UV screens, and nptII DNA for 18 months outside the international Space Station. Astrobiology 12:517-528

Vago JL, Westall F, Coates AJ, Jaumann R, Korablev O, Ciarletti V, Mitrofanov I, Josset J-L, De Sanctis MC, Bibring J-P (2017) Habitability on early Mars and the search for biosignatures with the ExoMars Rover. Astrobiology 17:471-510

Vreeland RH, Rosenzweig WD, Powers DW (2000) Isolation of a 250 million-year-old halotolerant bacterium from a primary salt crystal. Nature 407:897-900

Vreeland R, Jones J, Monson A, Rosenzweig W, Lowenstein T, Timofeeff M, Satterfield C, Cho B, Park J, Wallace A (2007) Isolation of live cretaceous (121-112 million years old) halophilic Archaea from primary salt crystals. Geomicrobiol J 24:275-282

Wall DB, Lubman DM, Flynn SJ (1999) Rapid profiling of induced proteins in bacteria using MALDI-TOF mass spectrometric detection of nonporous RP HPLC-separated whole cell lysates. Anal Chem 71:3894 3900

Wynn-Williams D, Newton E, Edwards H (2001) The role of habitat structure for biomolecule integrity and microbial survival under extreme environmental stress in Antarctica (and Mars?): ecology and technology. Exo-/astro-biology:225-237

Yang LF, Jiang JQ, Zhao BS, Zhang B, Feng DQ, Lu WD, Wang L, Yang SS (2006) A Na+/H+ antiporter gene of the moderately halophilic bacterium Halobacillus dabanensis D-8T: cloning and molecular characterization. FEMS Microbiol Lett 255:89-95

Zhou P, Wen J, Oren A, Chen M, Wu M (2007) Genomic survey of sequence features for ultraviolet tolerance in haloarchaea (family Halobacteriaceae). Genomics 90:103-109

Publisher's Note Springer Nature remains neutral with regard to jurisdictional claims in published maps and institutional affiliations.

\section{Affiliations}

\section{Niloofar Feshangsaz ${ }^{1}$ - Farid Semsarha ${ }^{2}$. Saeed Hesami Tackallou ${ }^{3} \cdot$ Kamran Nazmi $^{4}$. Euan P. Monaghan ${ }^{5}$ - Andreas Riedo ${ }^{5}$. Jack J. W. A. van Loon ${ }^{1,6}$}

Niloofar Feshangsaz

n.feshangsaz@gmail.com

1 Amsterdam UMC location VUmc, and Academic Centre for Dentistry Amsterdam (ACTA) Department of Oral and Maxillofacial Surgery/Pathology, Amsterdam Movement Sciences, Vrije Universiteit Amsterdam, Gustav Mahlerlaan 3004, 1081 LA Amsterdam, The Netherlands

2 Department of Biophysics, Mim Daroo Pharmaceutical Co., Tehran, Iran

3 Department of Biology, Central Tehran Branch, Islamic Azad University, Tehran, Iran

4 Academic Centre for Dentistry Amsterdam (ACTA) Department of Oral Biochemistry, ACTA-Vrije Universiteit, Amsterdam, The Netherlands

5 Laboratory for Astrophysics, Leiden Observatory, Leiden University, Leiden, The Netherlands

6 European Space Agency (ESA), Technology Center (ESTEC), TEC-MMG lab, Noordwijk, The Netherlands 